\title{
城市化对平原河网水系结构及功能的影响一以苏州市为例“
}

\author{
林芷欣,许有鹏“*,代晓颖,王强,袁甲 \\ (南京大学地理与海洋科学学院,南京 210023)
}

\begin{abstract}
摘 要: 针对城市化对平原河网水系结构的影响所引起的洪涝灾害频发等一系列水文问题,以我国典型平原河网地区苏 州市为例, 根据不同城市化程度分为主城区、市辖区、其他市县区,基于 1991、2001 和 2015 年三期遥感影像与 1960s、 $1980 \mathrm{~s}$ 和 $2010 \mathrm{~s}$ 三个时期的水系数据, 应用 RS/GIS 等技术, 构建水系结构参数指标, 重点探讨了城市化对河网水系结构及 功能的影响. 结果表明: 城镇用地迅速增长, 主要以牺牲水田、水域等土地利用方式为代价, 到 2015 年全区城镇用地面积 所占比重已达到 $41.35 \%$, 土地利用类型的变化规律与城市化进程的差异性保持一致; 水系结构变化主要受城市化影响, 且基本与城市化进程呈现同步性. 近 50 年来, 全区的水面率、河网密度、支流发育系数、主干河流面积长度比、河网复杂度 和河网结构稳定度分别减少了 $19.63 \% 、 6.91 \% 、 7.34 \% 、 1.06 \% 、 5.49 \%$ 和 $7.87 \%$, 城市化水平与各指数均呈负相关关系; 人 类活动不仅直接影响河流功能, 也间接地通过改变平原河网的水系结构导致其功能发生改变, 如河网调蓄能力下降、河 流生态功能受损等. 该研究为城市化地区河流水系保护及防洪减灾提供参考与理论支撑.
\end{abstract}

关键词: 城市化;河网水系结构;河流功能;苏州市

\section{Effect of urbanization on the river network structure and functions - A case study in Suzhou City}

\author{
LIN Zhixin, XU Youpeng ** , DAI Xiaoying, WANG Qiang \& YUAN Jia \\ (School of Geographic and Oceanographic Sciences, Nanjing University, Nanjing 210023, P.R.China)
}

\begin{abstract}
This paper centers on a series of urban hydrological problems like flood and waterlogging disasters resulting from the impacts of urbanization on river network structure. In this paper, Suzhou City, one of the typical plain river network areas in China, is taken as an object of the study. Based on different stages of urbanization, Suzhou City is divided into main urban district, municipal district and other county-level district. This research conducts both qualitative and quantitative analysis with the help of the remote sensing images in 1991, 2001 and 2015, as well as the stream data in 1960s, 1980s and 2010s, focusing on the influence of urbanization on the river network structure and functions. The study shows that: With the rapid development of urbanization, urban space continues to expand at the expense of farmland and water area primarily. The proportion of urban land in Suzhou City has reached $41.35 \%$ by 2015 . The change rules of land-use type are basically consistent with different stages of urbanization. The change of river system structure is mainly affected by urbanization, which remains synchronized with such process. In the past 50 years, water rate, drainage density, tributary development coefficient, river area length ratio, drainage complexity, and drainage network structure stability have decreased by $19.63 \%, 6.91 \%, 7.34 \%, 1.06 \%, 5.49 \%$ and $7.87 \%$, respectively in Suzhou City. Also, there exists negative correlations between urbanization level and each index. Human activities not only directly affect the functions of rivers, but also change the functions of rivers indirectly by changing the river system structure of the plain river network. The study serves as reference and theoretical support for the protection of river system and the flood control in urban areas. Keywords: Urbanization; river network structure; functions of river; Suzhou City
\end{abstract}

河湖水系是水资源的载体, 是生态环境的重要组成部分, 是经济社会发展的重要支撑 ${ }^{[1]} .20$ 世纪以来,

* 国家重点基础研发计划项目 (2016YFC0401502)、国家自然科学基金项目 (41771032) 和江苏水利基金重大项目 (2015003) 联合资助. 2017-12-26 收稿; 2018-03-20 收修改稿. 林芷欣(1993 ), 女, 硕士研究生; E-mail: linzhixin115@163.com.

** 通信作者; E-mail:xuyp305@163.com. 
快速城市化进程下, 人类活动频繁, 对河流系统产生了深刻的影响, 全球 $60 \%$ 的河流随着城市化进程而改 变 ${ }^{[2]}$. 而城市化进程中, 不透水地面的增加对地表径流产生了显著影响 ${ }^{[3]}$, 导致城市化地区洪涝灾害频发、 河流功能受到影响、生态问题严峻,对人类社会的可持续发展造成严重威胁.

早在 $1950 \mathrm{~s}$, Horton $^{[4]}$ 和 Strahler ${ }^{[5]}$ 提出了著名的 Horton 定律和 Strahler 河流分级方法, 为河流结构研究 奠定基础. 近年来, 随着城市化进程的不断推进, 学者们就城镇化对河流水系及功能的影响展开了广泛的讨 论. 城市化使得不透水面积增加、地下管网增加、河道渠化 ${ }^{[6-7]}$, 造成汇流时间缩短、洪峰流量增大、径流系数 增大等一系列影响 ${ }^{[8-10]}$, 从而使得城市区域河网调蓄能力下降 ${ }^{[11]}$ 、河流水质恶化 ${ }^{[12]}$ 等水安全、水环境问题 日渐显著. 伴随着人类日益增长的生活需求, 河流从原先的供水、防洪调蓄、自净水体等功能, 逐渐具有更多 元化的功能, 如景观、生态功能等. 不少高度城市化地区水系大幅度衰退, 失去了至少 $85 \%$ 的河道 ${ }^{[13]}$, 美国 密西根地区、加利福尼亚州、大西洋沿岸地区水系已出现城市河流沙漠区域 (即无水系区 $)^{[14-16]}$. 而中国进人 快速城市化较晚, 其中, 长江三角洲的上海地区 ${ }^{[17-18]}$ 、太湖流域 ${ }^{[19-20]}$ 和珠江三角洲地 区 $^{[21-22]}$ 等快速城市化的 平原河网区, 成为近年来城市化水文效应研究的热点区域. 现有研究均表明, 快速城市化地区河流水系剧烈 衰减 ${ }^{[23]}$, 河流功能受到一定程度的影响, 譬如上海地区河流结构呈现自然型 $\rightarrow$ 井型 $\rightarrow$ 干流型演变趋势 ${ }^{[24]}$, 城市化过程中永定河流域京津段水系调蓄能力下降, 在同样的致灾强度下水灾危险性加大 ${ }^{[25]}$. 而在流域自 然特性差异和复杂人类活动干扰下, 不同地区水系变化的特征表现可能会有所不同, 因此城市化进程中平 原河网地区水系演变规律、以及其对河流功能的影响等一系列城市化下水文问题亟待进一步深人探究.

太湖流域是我国高度城市化地区, 城市化的快速发展有力地促进了区域经济的增长, 但同时日益剧烈 的人类活动对原有河流水系造成了较大冲击, 从而对生态环境造成了很大影响. 苏州市位于太湖流域腹部, 是该地区城市化发展最为典型的城市之一, 也是我国经济最为发达地区之一. 区内湖泊众多, 水系纵横交 错, 水面率较大, 是典型的平原河网地区, 具有代表性; 近几十年来城市化的快速发展致使区域河网萎缩, 不 透水面积大量增加, 亟待深人探讨城市化与河流系统之间的关系. 因此, 本文针对苏州市河网水系的典型 性, 结合下垫面与水系结构参数时空变化, 探讨苏州市不同城市化进程对河流水系结构及功能的影响, 为改 善平原水网地区水系结构以及健全河流功能提供基础支撑, 并且为我国城市化地区河流水系保护及其区域 防洪减灾提供参考.

\section{1 研究区概况}

苏州市 $\left(30.76^{\circ} \sim 32.04^{\circ} \mathrm{N}, 119.91^{\circ} \sim 121.33^{\circ} \mathrm{E}\right)$ 属太湖流域腹部地区 (图 1). 区域地形以平原为主, 地势 低平, 区内湖荡众多, 河道密集, 水面率较高. 全市拥有各等级河道 2 万余条、湖泊 323 个. 其地处亚热带季 风气候区, 热量充足, 降水充沛. 全区多年平均气温 $15.7^{\circ} \mathrm{C}$, 年均降水量 $1100 \mathrm{~mm}$. 受季风强弱变化影响, 降 水年际变化明显,且年内分配不均. 苏州市常住总人口 1061 万人 (2015 年末), 城镇化水平超过 $70 \%{ }^{[26]}$. 高 速的城市化进程与剧烈的人类活动对河网水系结构产生了较为深刻的影响. 随着苏州城市化不断加速, 城 镇用地面积比重不断加大, 其河网水系结构遭受到不同程度的破坏, 许多河道被填埋、淤堵, 产汇流机制改 变,致使苏州市的城市洪涝灾害频繁发生,严重影响了经济发展和社会稳定.

\section{2 数据与方法}

\section{1 数据基础}

本文数据主要包括遥感影像与水系数据. 其中, 遥感影像选取 1991、2001、2015 三个时期的 Landsat TM、 $\mathrm{ETM}^{+}$影像, 分辨率均为 $30 \mathrm{~m}$, 进行几何校正、图像剪裁、重分类等处理, 参考中国土地资源分类系统, 且根据 研究区土地覆被类型特点和研究需要进行土地利用类型解译, 其解译精度均在 $80 \%$ 以上, Kappa 系数达到 0.80 .

采用三期水系数据,其中 $1960 \mathrm{~s}$ 和 $1980 \mathrm{~s}$ 水系数据由 $1: 50000$ 分幅地形图中数字化提取, $2010 \mathrm{~s}$ 水系数 据源自 1:50000 数字线划图 (DLG) 并利用高分辨率遥感影像进行校核. 由于研究区地处平原水网区, 河道 纵横交错, 难以按照传统的 Strahler 规则进行河流分级. 根据河流自然形态与社会功能特性, 考虑河流宽度 进行分级:河宽大于 $20 \mathrm{~m}$ 的双线河、湖泊分为一级河流 (主干河流)、粗单线河 (河宽介于 $10 \sim 20 \mathrm{~m}$ 之间) 为 


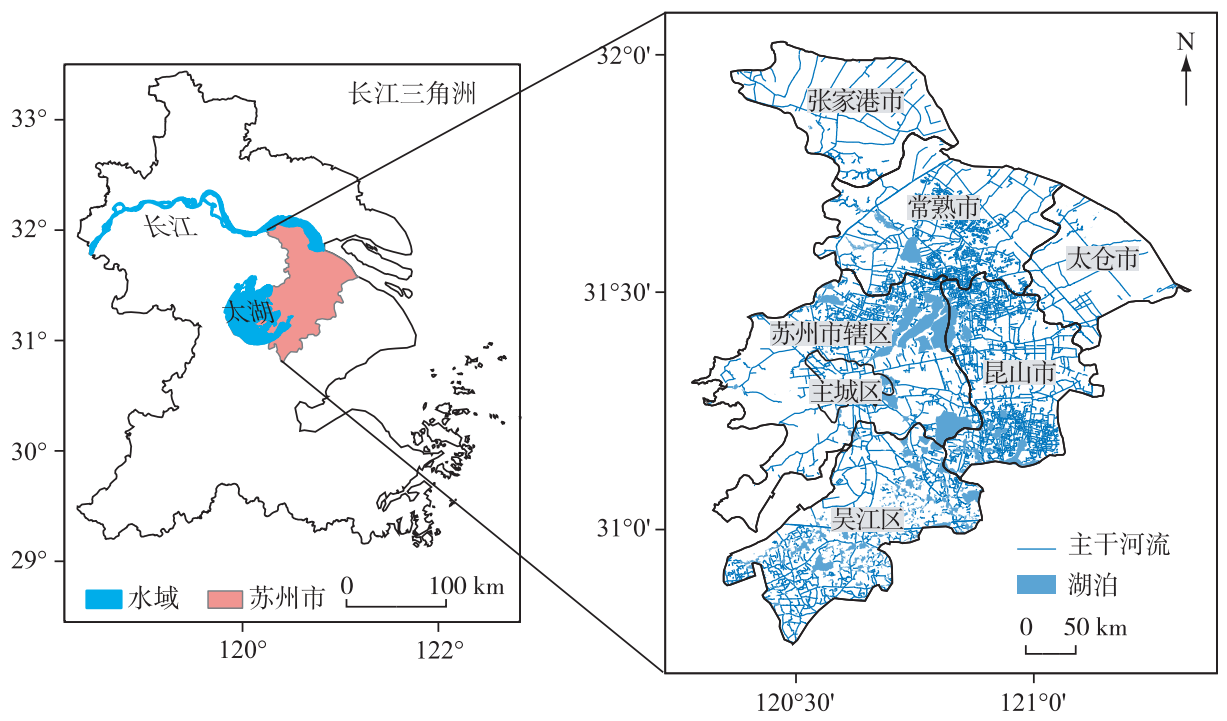

图 1 研究区示意图

Fig.1 Location of the research area

二级河流 (平均宽度为 $15 \mathrm{~m}$ ) 、细单线河 (河宽不足 $10 \mathrm{~m}$ ) 与未连通单线河 (河宽不足 $10 \mathrm{~m}$ ) 则为三级河流 (平均宽度为 $5 \mathrm{~m})^{[20,23]}$.

\section{2 水系结构参数}

平原河网地区是河流高度发育并受到城市化深刻影响的区域 ${ }^{[18]}$, 不同于山区自然状态下的河流系统, 有其独有的河流发育特点. 参考平原地区河网结构研究相关文献 ${ }^{[17-18,23,27]}$, 结合研究区城市化特点, 本研究 构建水系结构参数指标对各时期的河网水系变化进行定量分析,包括河网密度 $(D d)$ 、水面率 $(W p)$ 、支流发

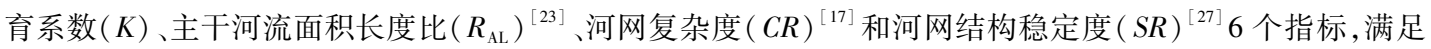
刻画平原区河流形态、水系结构及演化规律的需求, 以此揭示河网水系的内在结构与功能的变化特征.

2.2.1 水系数量特征 1) 水面率 ( WP ) : 区域内河湖总面积占流域总面积的比重, 是河流水系中常见的数量分 析指标.

$$
W p=\left(A_{\mathrm{w}} / A\right) 100 \%
$$

式中, $A_{\mathrm{w}}$ 为河湖总面积, $A$ 为流域总面积.

2 ) 河网密度 $(D d)$ : 描述水系发育与分布的疏密程度,其值越大, 表明流域内调蓄能力越强, 反之亦然.

$$
D d=L_{\mathrm{R}} / A
$$

式中, $L_{\mathrm{R}}$ 为河流总长度.

2.2.2 结构特征 1) 支流发育系数 $(K)$ : 表示水系干流与支流的发育情况, 其值越小, 表明河流主干化程度趋 于明显.

$$
K=L_{\mathrm{b}} / L_{\mathrm{m}}
$$

式中, $L_{\mathrm{b}}$ 表示二级、三级河流 (即支流) 总长度, $L_{\mathrm{m}}$ 为一级河流 (即主干流) 总长度.

$2)$ 主干河流面积长度比 $\left(R_{\mathrm{AL}}\right)$ : 其值越大, 说明单位长度的的河流水面积越大, 则河流的过水能力越强.

$$
R_{\mathrm{AL}}=A_{\mathrm{m}} / L_{\mathrm{m}}
$$

式中, $A_{\mathrm{m}}$ 为主干河流面积.

2.2 .3 复杂性与稳定性特征 1$)$ 河网复杂度 $(C R)$ : 描述河网数量和长度的发育程度, 其数值越大, 表明该区 域的河网构成层次越丰富, 其支流水系越发达, 河网结构越复杂.

$$
C R=N_{\mathrm{c}}\left(L_{\mathrm{R}} / L_{\mathrm{m}}\right)
$$


式中, $N_{\mathrm{c}}$ 表示河网等级数.

$2)$ 河网结构稳定度 $(S R)$ : 表示不同阶段河网长度与河道面积的比值, 河网结构的变化导致河流长度与 面积演化的不同步性,此指标可描述不同阶段下河网结构的稳定程度.

$$
S R_{t}=\left(L_{t} / R A_{t}\right) /\left(L_{t-n} / R A_{t-n}\right)(n>0, t>n)
$$

式中, $S R_{t}$ 表示第 $t$ 年时, 河网在过去 $n$ 年时间的稳定度, $L_{t} 、 R A_{t}$ 和 $L_{t-n} 、 R A_{t-n}$ 分别表示在第 $t$ 年和第 $t-n$ 年的 河流总长度、河流总面积.

\section{3 结果与讨论}

\section{1 城市化发展}

研究区内城市发展快速, 频繁的人类活动对河流系统的影响也日益显著, 其中土地利用/覆被变化引起 的区域下垫面条件变化尤为剧烈 (图 2). 故而,本文采取土地城市化指标衡量城市化发展水平,对各区不同 时期城镇用地面积进行统计 (表 1), 结果表明 1991-2015 年期间各区城镇面积均呈增加趋势, 增加幅度均 较大, 具有较高的城市化水平, 其中 1991-2001 年增幅最大的为吴江, 从 $29.49 \mathrm{~km}^{2}$ 增加到 $223.27 \mathrm{~km}^{2}$, 增幅 最小的是张家港; 2001-2015 年增幅最大的为太仓, 从 $54.02 \mathrm{~km}^{2}$ 增加到 $244.44 \mathrm{~km}^{2}$, 苏州主城区城镇用地有 所减少,是为维持良好的城市生态环境,城市绿化逐步增加,部分水域扩宽的缘故.

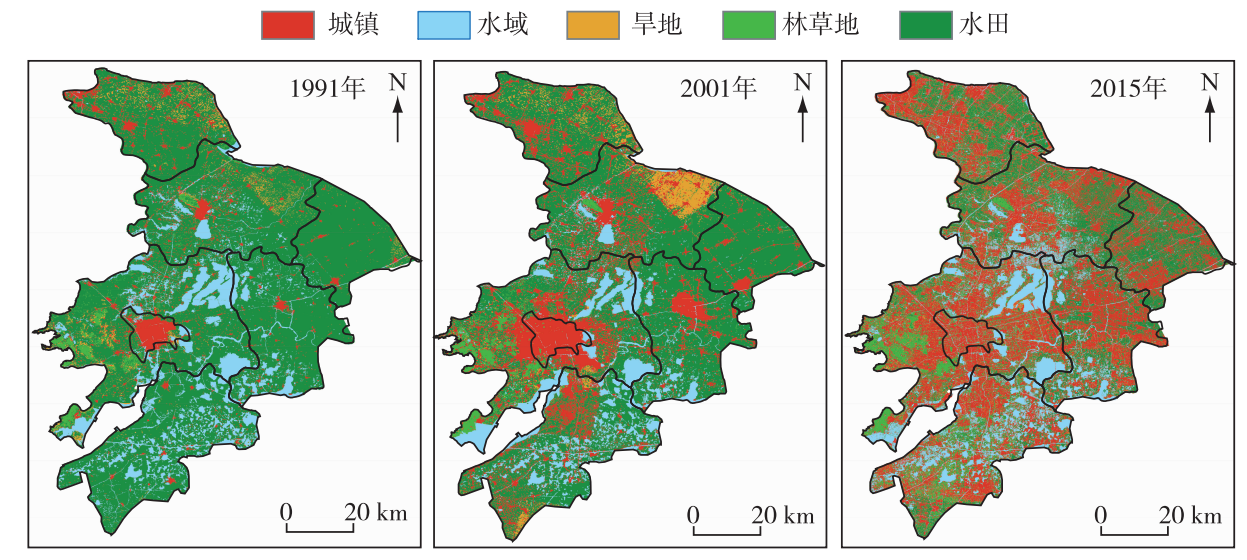

图 2 研究区土地利用变化情况

Fig. 2 Land use changes in Suzhou City

表 1 不同时期各区城镇用地面积

Tab.1 Areas of urban land in different areas during different periods

\begin{tabular}{cccccccc}
\hline 时期 & $\begin{array}{c}\text { 苏州 } \\
\text { 主城区 } / \mathrm{km}^{2}\end{array}$ & $\begin{array}{c}\text { 苏州 } \\
\text { 市辖区 } / \mathrm{km}^{2}\end{array}$ & $\begin{array}{c}\text { 张家港/ } \\
\mathrm{km}^{2}\end{array}$ & $\begin{array}{c}\text { 常熟/ } \\
\mathrm{km}^{2}\end{array}$ & $\begin{array}{c}\text { 太仓/ } \\
\mathrm{km}^{2}\end{array}$ & $\begin{array}{c}\text { 昆山/ } \\
\mathrm{km}^{2}\end{array}$ & $\begin{array}{c}\text { 吴江/ } \\
\mathrm{km}^{2}\end{array}$ \\
\hline 1991 年 & 74.44 & 86.05 & 113.58 & 84.17 & 16.71 & 31.46 & 29.49 \\
2001 年 & 121.62 & 427.97 & 168.3 & 233.2 & 54.02 & 141.05 & 223.27 \\
2015 年 & 119.18 & 754.01 & 352.23 & 436.80 & 244.44 & 404.67 & 443.28 \\
\hline
\end{tabular}

对各区 1991、2001 和 2015 年城市化水平及城市化速率进行计算(表 2), 结果表明各区城市化发展速率 存在一定差异. 苏州主城区城市化较早, 城市化水平较高. 苏州市辖区相较于主城区进人城市化晚一些, 1991－2001 年城市化速度快,此后仍保持较快发展速度. 其余 5 市县区域自 2001 年后城市化发展迅速, 城 市化水平增幅仅为 $20 \%$ 左右, 到 2015 年城市化水平均达到 $35 \%$ 以上, 特别是太仓和昆山, 城市化速率分别 达到 $2.33 \%$ 和 $2.18 \%$. 因此, 根据城市化发展进程将研究区划分为主城区、市辖区和其他市县区, 进一步阐述 城市化对水系结构的影响. 
表 2 不同时期内各区域城市化水平及速率 *

Tab. 2 The level land rate of urbanization in different areas during different periods

\begin{tabular}{|c|c|c|c|c|c|c|}
\hline \multirow{2}{*}{ 区域 } & \multicolumn{3}{|c|}{ 城市化水平/\% } & \multicolumn{3}{|c|}{ 城市化速率/\% } \\
\hline & 1991 年 & 2001 年 & 2015 年 & $1991-2001$ 年 & $2001-2015$ 年 & $1991-2015$ 年 \\
\hline 苏州主城区 & 52.49 & 85.90 & 84.18 & 3.34 & -0.13 & 1.38 \\
\hline 苏州市辖区 & 5.65 & 28.14 & 49.58 & 2.25 & 1.65 & 1.91 \\
\hline 张家港 & 11.29 & 16.75 & 35.05 & 0.55 & 1.41 & 1.03 \\
\hline 常熟 & 6.91 & 19.18 & 35.89 & 1.23 & 1.29 & 1.26 \\
\hline 太仓 & 2.65 & 8.61 & 38.90 & 0.60 & 2.33 & 1.58 \\
\hline 昆山 & 3.38 & 15.20 & 43.56 & 1.18 & 2.18 & 1.75 \\
\hline 吴江 & 2.41 & 18.31 & 36.33 & 1.59 & 1.39 & 1.47 \\
\hline 全区 & 6.67 & 20.57 & 41.35 & 1.39 & 1.60 & 1.51 \\
\hline
\end{tabular}

* 城市化指标采用土地城市化指标.

\section{2 河网水系结构演变}

3.2.1 水系总体特征 苏州市所处平原河网地区, 涉及到阳澄淀泖区和杭嘉湖浦南区两大水利片区, 乃全国 河网水系最密集的地区, 具有“地区性河网依附骨干河网, 地区性河网又包裹着圩区水网 ${ }^{[18]}$ ”的特点. 50 年 来, 苏州市干流与支流均呈明显的减少趋势, 特别是 1980s-2010s 的水系变化更为显著 (图 3). 从河道总面 积来看, 呈现持续减少的趋势, $1960 \mathrm{~s}$ 为 $428.25 \mathrm{~km}^{2}$, 到 $1980 \mathrm{~s}$ 减少了 $0.07 \%$, 到 $2010 \mathrm{~s}$ 减幅更为剧烈, 仅剩

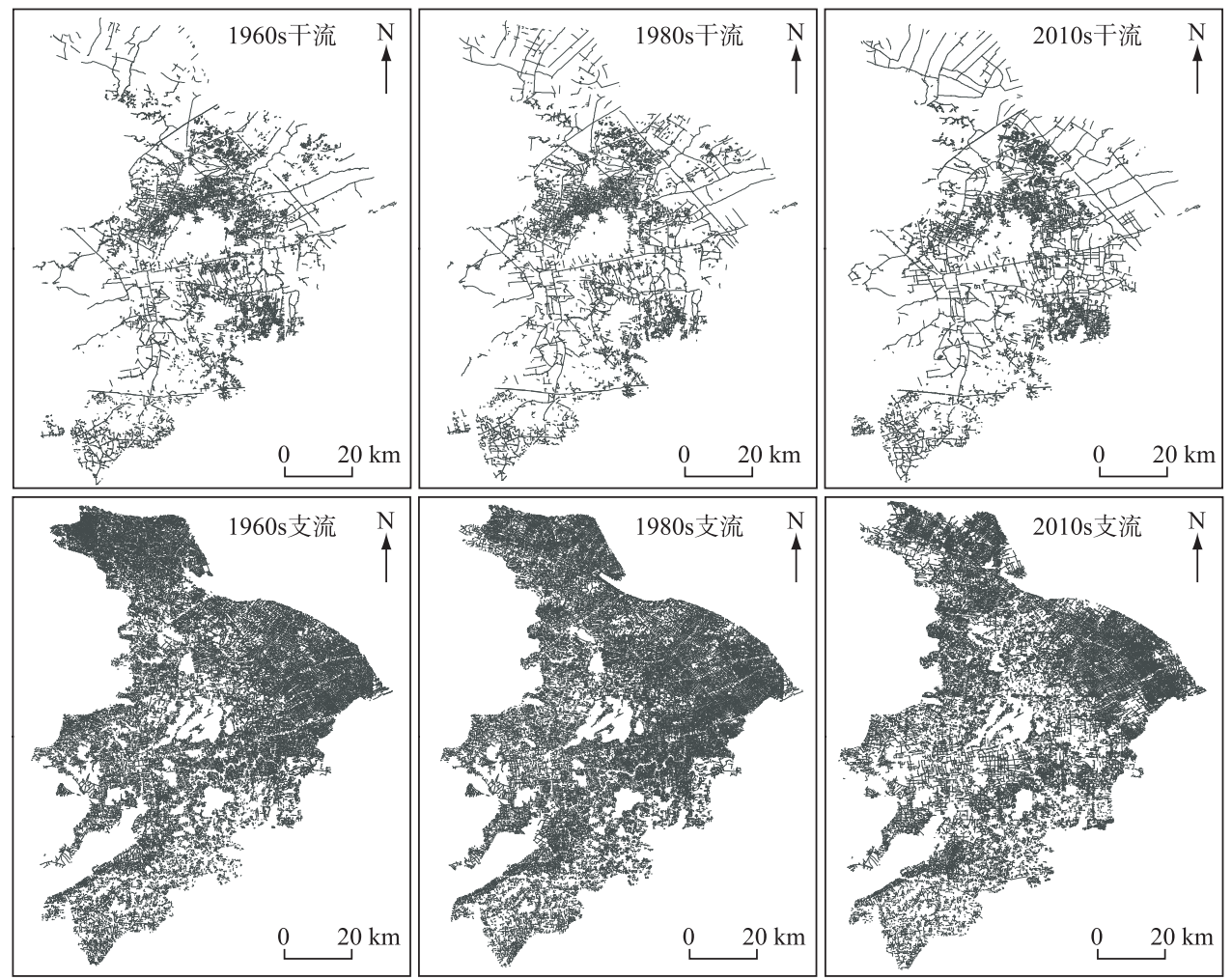

图 350 年间苏州市河流演化

Fig.3 River evolution of Suzhou City in 50 years 
$379.55 \mathrm{~km}^{2}$. 而不同时期各级河流总长度的统计结果表明, 1960s - 1980s 期间一级和二级河流长度显著衰 减, 分别减少了 $4.67 \%$ 和 $23.83 \%$, 三级河流增幅剧烈, 为 $60.48 \% .1980 \mathrm{~s}-2010 \mathrm{~s}$ 是苏州市高速城市化发展阶 段, 该时期河流长度变化所显现出的特点是一级河流呈增大趋势, 增加了 $2.11 \%$, 二、三级河流均呈减少趋 势,分别减少了 $18.79 \%$ 和 $11.82 \%$, 河流总长度持续缩短, 由 $23906.14 \mathrm{~km}$ 减少至 $21317.42 \mathrm{~km}$.

近 50 年来,苏州市全区水系结构变化总体上呈衰减趋势 (表 3). 值得关注的是,水面率呈持续不断的衰 减状态. 其他水系结构参数在 1960s-1980s 有不同程度的增加, 河流系统的发育状态良好, 而 1980s 后各项 指标趋于减小. 其中, 描述水系干流与支流的发育情况的支流发育系数受影响最深, 也正反应了高速的城市 化发展时期对河流系统的影响之大. 城市化下河流演化呈现出支流衰减剧烈、主干河流相对稳定的趋势, 河 网结构趋于简单化、不稳定.

表 3 近 50 年苏州市全区水系结构特征变化

Tab.3 Changes of river structure characteristics of Suzhou City in recent 50 years

\begin{tabular}{cccccccc}
\hline & 水系结构参数 & $1960 \mathrm{~s}$ & $1980 \mathrm{~s}$ & $2010 \mathrm{~s}$ & $1960 \mathrm{~s}-1980 \mathrm{~s} / \% 1980 \mathrm{~s}-2010 \mathrm{~s} / \% 1960 \mathrm{~s}-2010 \mathrm{~s} / \%$ \\
\hline 数量特征 & 水面率 $(W p)$ & 15.66 & 14.51 & 12.59 & -7.33 & -13.28 & -19.63 \\
& 河网密度 $(D d)$ & 3.52 & 3.77 & 3.28 & 7.15 & -13.12 & -6.91 \\
结构特征 & 支流发育系数 $(K)$ & 2.97 & 3.41 & 2.75 & 14.89 & -19.35 & -7.34 \\
& 主干河流面积长度比 $\left(R_{\mathrm{AL}}\right)$ & 43.27 & 47.54 & 42.82 & 9.86 & -9.93 & -1.06 \\
复杂性与稳定性 & 河网复杂度 $(C R)$ & 11.91 & 13.24 & 11.26 & 11.14 & -14.97 & -5.49 \\
& 结构稳定度 $(S R)$ & - & 1.07 & 0.99 & - & -7.87 & - \\
\hline
\end{tabular}

3.2.2 水系分区时空特征 为探讨城市化与水系演变之间的关系, 进一步分析高度城市化地区内部的水系演 化分异特征. 近 50 年各分区的河道总面积均呈持续减少的趋势, 1960s - 1980s 期间其他市县区河道面积减 少最为剧烈, 减幅高达 $9.93 \%$; 其次为主城区; 市辖区减幅最小, 为 $4.56 \% .1980 \mathrm{~s}-2010 \mathrm{~s}$ 进人城市化高速发 展阶段,三个分区河道总面积减幅差异明显, 较早进人城市化的主城区河道总面积减少了 $25.8 \%$; 市辖区减 少了 $17.95 \%$; 而其他市县区该时期的减幅与 $1960 \mathrm{~s}-1980 \mathrm{~s}$ 相当, 为 $9.71 \%$. 三个时期各级河流长度比例表 现出区域差异 (图 4): 主城区的一、三级河道比例随着城市化发展有所增加, 水系明显趋于主干化. 市辖区 各河道比重变化趋势不如中心城区显著,一、二级河道均呈先减少后增加的变化趋势, 三级河道则相反, 呈 先增加后减少趋势; 其各级河道所占比重较均匀. 其他市县区各级河道比重变化趋势各不相同, 一级河道呈 先减少后略微增加的趋势, 二级河道呈持续减少的趋势, 三级河道呈先大幅度增加后略微减少的趋势.

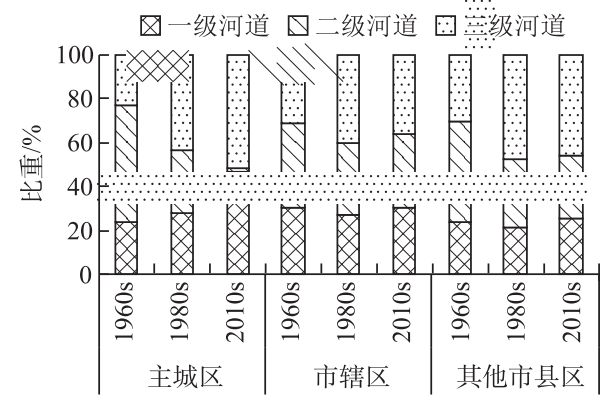

图 4 苏州市 50 年间各区不同等级河道长度所占比重

Fig.4 Percentage of different orders in stream length during 50 years in different areas in Suzhou City

就水系数量特征而言 (图 5), 在 1960s - 2010s 期间市辖区的水面率变化最大, 在 $16.55 \% \sim 21.14 \%$ 之间, 其他市县区水面率变化最小, 在 $11.41 \% \sim 13.98 \%$ 之间. 而从年代变化来看, 各区在 $1960 \mathrm{~s}-2010 \mathrm{~s}$ 呈持续下 降趋势,变化幅度从大到小依次为主城区、市辖区和其他市县区, 分别为 $-29.93 \%,-21.71 \%$ 和 $-18.38 \%$. 就 河网密度来看, 其他市县区河网密度最大,均在 3.64 $4.05 \mathrm{~km} / \mathrm{km}^{2}$ 之间, “先增加后减少” 的变化趋势与全 
区一致. 而主城区与市辖区河网密度较小,均为 $2.0 \sim 3.0 \mathrm{~km} / \mathrm{km}^{2}$ 左右, 而其不同年代变化差异明显, 主城区 自 1960s - 2010s 均呈持续减小趋势, 其中 1980s - 2010s 期间主城区河网密度减少幅度剧烈, 达到 39.24\%, $2010 \mathrm{~s}$ 河网密度仅为 $1.84 \mathrm{~km} / \mathrm{km}^{2}$. 市辖区则相反, 先小幅度增加后减少.

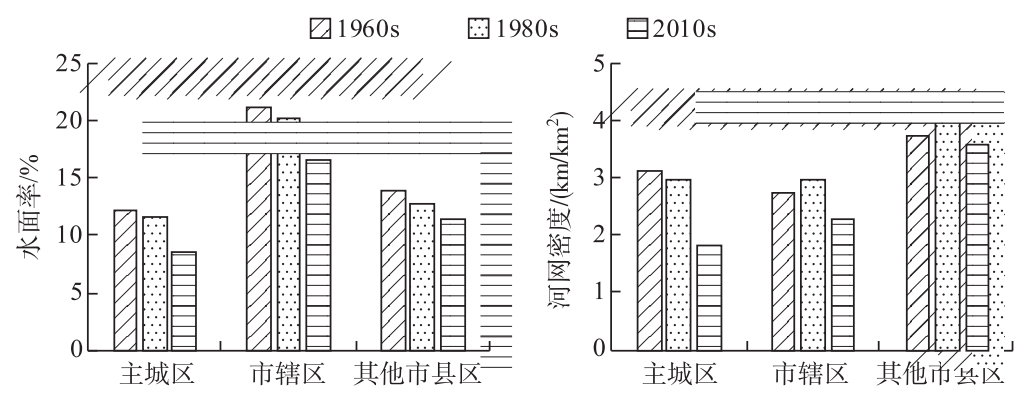

图 5 苏州市不同分区水面率与河网密度

Fig.5 Water rate and drainage density in different areas in Suzhou City

从水系结构特征来看, 整体上市辖区主干河流面积长度比 $R_{\mathrm{AL}}$ 值最大, 均在 $50.4 \times 10^{-3} \sim 56.91 \times 10^{-3} \mathrm{~km}^{2} / \mathrm{km}^{-}$ 之间, 河流过水能力最强. 其他市县区最小, 主要在 $40.36 \times 10^{-3} \sim 44.69 \times 10^{-3} \mathrm{~km}^{2} / \mathrm{km}$ 之间 (图 6). 而从各区 年代变化趋势来看, $1960 \mathrm{~s}-1980 \mathrm{~s}$ 各区均呈增大趋势, 其增幅从小到大依次为主城区、其他市县区、市辖区; $1980 \mathrm{~s}-2010 \mathrm{~s}$ 主城区持续增大, 市辖区与其他市县区呈减小趋势. 而主城区的支流发育系数 $K$ 值在 $1960 \mathrm{~s}$ 为 3.21 , 到 $1980 \mathrm{~s}$ 下降了 $21.14 \%, 1980 \mathrm{~s}-2010 \mathrm{~s}$ 期间下降至 1.14 ,下降了 $54.94 \%$, 减幅更为剧烈. 而市辖区 $K$ 值则呈现出先增大后减小的变化规律, 其他市县区的支流发育系数变化趋势与市辖区一致, 但更为剧烈. 随 着城市化的推进, 支流大幅度缩短, 对河流的结构受到严重干扰.

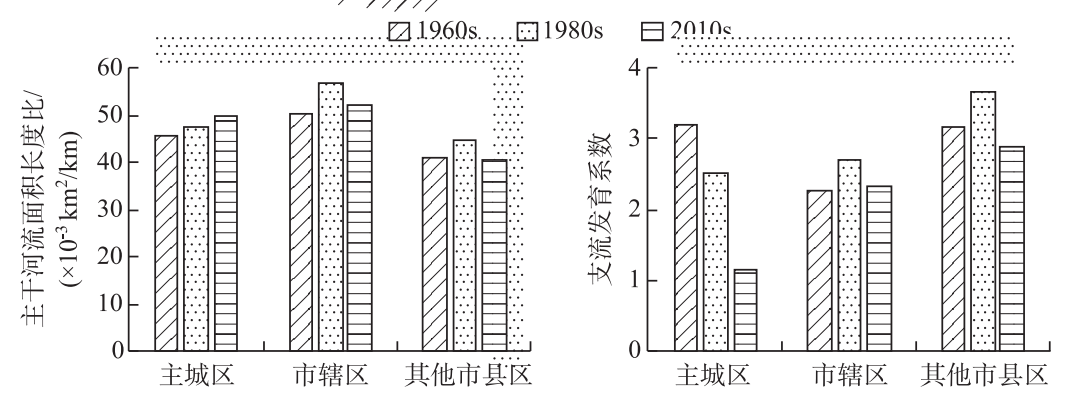

图 6 苏州市不同分区主干河流面积长度比和支流发育系数

Fig.6 Area length ratio of main river and tributary development coefficient in different areas in Suzhou City

在 $1960 \mathrm{~s}-1980 \mathrm{~s}$ 主城区河网复杂度 $C R$ 值下降, 河网结构趋于简化, 而市辖区与其他市县区河网复杂度 均呈增加的趋势. 此后进人城市化高速发展时期, $1980 \mathrm{~s}-2010 \mathrm{~s}$ 河网复杂度均呈减少趋势, 但在空间上减少 幅度表现不均衡, 主城区最为显著, 依次为其他市县区、市辖区. 全区的河网结构稳定性随着城市化不断推进 而减弱, 在 $1960 \mathrm{~s}-1980 \mathrm{~s}$ 各分区的结构稳定度 $S R$ 值均高于 1 , 说明其河网发育较为稳定, 河流长度与面积 发育较为均衡. 而 $1980 \mathrm{~s}-2010 \mathrm{~s}$, 各分区河流稳定程度均有所下降, 主城区河网结构最不稳定, $S R$ 值仅为 0.76 , 市辖区和其他市县区的 $S R$ 值分别为 0.99 和 0.98 . 由此表明城市化水平越高, 河网复杂度下降愈加明 显, 河网结构趋于简单, 河网稳定程度愈加差 (图 7).

\section{3 城市化对河流结构及功能的影响}

对于快速发展中的苏州市而言, 随着城市化发展水平不断提高, 结果表明区域整体水系结构日趋衰弱, 区域内部因不同城市化进程而水系衰减程度不一. 河网水系变化趋势为由复杂到简单、由多元到单一, 河网 主干化、简单化趋势明显, 河网结构稳定性受到一定程度影响. 城市化对支流的影响大于主干河流, 河流的 


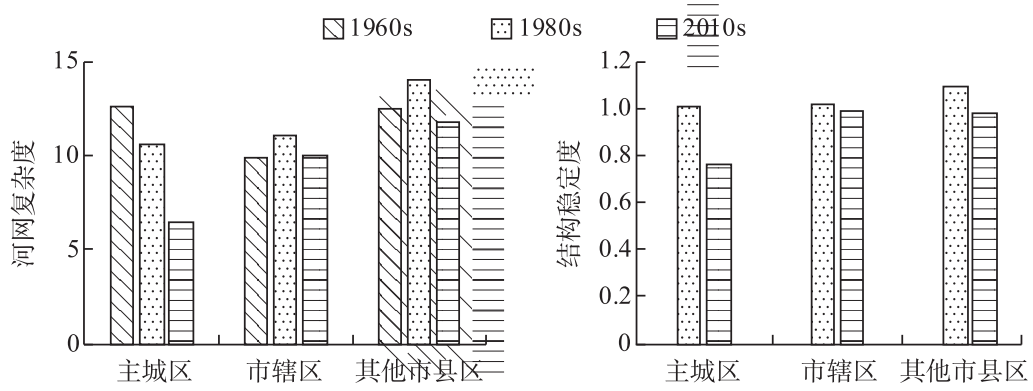

图 7 苏州市各分区不同时期河网复杂度与结构稳定度

Fig.7 Drainage complexity and drainage network structure stability in different areas in Suzhou City

行洪、排涝能力主要由主干河流承担, 大量的支流更易被掩埋、侵占. 城市化发展到一定的程度, 城市洪涝灾 害频发, 造成大量经济与社会损失, 城市防洪压力愈大, 主干河流的重要性日趋凸显. 到了城市化发展后期, 出于减轻防洪排涝压力的目的,部分二级河道被进一步疏浚、扩宽为主干河道,主干河道则采取河道清淤、 保持其过水面积不变等措施. 城市化发展速度亦影响河网水系结构. 城市发展为了争取更大的发展空间,获 取更多的建设面积,牺牲了其他土地利用方式, 水域的侵占是最主要的形式之一. 城市发展速度越快, 水系 数量特征衰减越快, 结构特征发育越薄弱, 河网复杂度下降愈加明显, 河网结构趋于简单, 支流水系发育越 发薄弱,其由主干河道构成的河网结构稳定度越低.

为顺应城市发展需要, 高强度的人类活动改变了下垫面土地利用格局, 破坏了河流的自然演变规律以 及河流的水生态平衡, 对河流功能亦造成了不同程度的影响. 城市化等人类活动对河流功能的影响主要体 现在以下两方面:首先, 城市化导致不透水面积扩张、水域被侵占、河道淤积, 对河网调蓄能力的影响显 著 ${ }^{[18,25]}$, 从而加快了地表径流速度, 缩短了汇流时间, 增加了城市的防洪压力. 在太湖流域研究表明, 河流水 系的可调蓄能力在 $1960 \mathrm{~s}-2010 \mathrm{~s}$ 呈现 $20.3 \%$ 的下降 ${ }^{[28]}$, 但其变化存在较大的空间差异. 高等级河流蓄水功 能较强, 低等级河流调蓄功能更显著 ${ }^{[18]}$, 而城市化过程中低等级河流更易受影响而被填埋. 本文进一步对 苏州市 1960s 1980s 以及 2010s 的河道调蓄能力进行量化分析, 结果发现, 在 1960s - 2010s 期间苏州市总体 主干河网的单位面积可调蓄能力提升 $21 \%$,而一般河网总体可调蓄能力下降了 $7.7 \%$. 可见,城市化对河流 水系的调蓄能力造成较大影响,但对不同等级水系产生的影响存在一定差异.

另一方面, 城市河流多被阻隔与渠化, 阻碍了河流水系之间、河流与湖泊之间的连通, 从而影响了河流 功能. 根据苏州市 21 个水质监测断面的实测资料, 选取溶解氧、总氮、氨氮、总磷和高锰酸盐指数指标, 结合 单因子评价法 ${ }^{[29]}$ 对河流水质情况进行量化. 结果表明, 2015 年苏州市 IV 劣 V 类水质断面比重达到 $52.38 \%$, 总体水质较差. 丰水期洪涝频率与强度逐渐增加, 枯水季节河道水量骤减, 其涵养水源、调节气候和 净化环境的功能降低. 可见随着城市的扩张, 人口增加导致河流生态系统承受压力越来越大, 大量污、废水 排人河流, 从而导致河流的生态功能遭受破坏. 然而, 不仅河网结构的变化影响了河流功能, 水利工程设施 亦改变了区域水体之间的水利联系, 从而改变了天然的水文过程,一定程度改善了水质,但也对河流功能造 成了一系列胁迫效应 ${ }^{[30]}$.

\section{4 结论}

以我国典型平原河网地区苏州市为例, 重点探讨了城市化对河网水系结构及河流功能的影响. 研究 表明:

1) 研究区正处于快速城市化阶段, 城市由主城区向外围发展, 城市化主要体现在城镇用地的增加, 是以 占用水域、旱地、水田等土地类型为前提而发展起来的. 土地利用类型的变化规律与城市化进程的差异性保 持一致, 城市化水平越高, 其城镇用地增长越缓慢, 甚至是负增长, 城市化水平相对较低区域, 其城镇用地扩 张迅速, 区域水域面积的剧减对河网水系结构的影响尤为深刻.

2) 水系结构变化主要受城市化影响,且基本与城市化进程呈负相关性. 城市化进程的推进影响了河网 
水系结构, 由复杂到简单、由多元到单一. 城市化发展速度亦影响河网水系结构, 发展速度越快, 水系数量特 征衰减越快, 结构特征发育越薄弱, 河网复杂度下降愈加明显, 河网结构趋于简单, 支流水系发育越发薄弱, 其由主干河道构成的河网结构稳定度越低. 总的来说, 城市化水平与水面率、河网密度、支流发育系数、主干 河流面积长度比、河网复杂度、河网结构稳定度均呈负相关关系

3) 人类活动不仅直接影响河流功能, 也间接地通过改变平原河网的水系结构导致河流的功能发生改 变. 而快速城市化下河流的水系结构、形态改变造成了河流调蓄能力下降、防洪压力增加. 河道的渠化现象 对河流的水量、水质等指标造成了一定程度的影响, 河流自净能力不足以维持河流健康, 水生态问题显著, 河流功能的重要性不容忽视.

\section{5 参考文献}

[ 1 ] Li YY, Li JQ, Li ZL et al. Issues and challenges for the study of the interconnected river system network. Resources Science, 2011, 33(3) : 386-391. [李原园, 畉建强, 李宗礼等. 河湖水系连通研究的若干问题与挑战. 资源科学, $2011,33(3)$ : 386-391.]

[ 2 ] Surian N, Rinaldi M. Morphological response to river engineering and management in alluvial channels in Italy. Geomorphology, 2003, 50(4) : 307-326.

[ 3 ] Corbett DR, Chanton J, Burnett W et al. Patterns of groundwater discharge into Florida Bay. Limnology and Oceanography, 1999, 44(4) : 1045-1055.

[ 4 ] Horton RE. Erosional development of streams and their drainage basins, hydrophysical approach to quantitative morphology. Journal of the Japanese Forestry Society, 1945, 56(3) : 275-370.

[ 5 ] Strahler AN. Quantitative analysis of watershed geomorphology. Transactions American Geophysical Union, 1957, 38(6): 913-920.

[ 6 ] Gregory KJ, Davis RJ, Downs PW. Identification of river channel change to due to urbanization. Applied Geography, 1992, 12(4) : 299-318.

[ 7 ] Hammer TR. Stream channel enlargement due to urbanization. Water Resources Research, 1972, 8( 6) : 1530-1540.

[ 8 ] Hollis GE. The effect of urbanization on floods of different recurrence interval. Water Resources Research, 1975, 11(3): 431-435.

[ 9 ] Brown RG. Effects of precipitation and land use on storm runoff. Water Resources Bulletin, 1988, 24(2) : 421-426.

[10] Ng HYF, Marsalek J. Sensitivity of streamflow simulation to changes in climatic inputs. Nordic Hydrology, 1992, 23(4) : 257-272.

[11] Vicars-Groening J, Williams HFL. Impact of urbanization on storm response of White Rock Creek, Dallas, TX. Environmental Geology, 2007, 51(7): 1263-1269.

[12] Schueler TR. The importance of imperviousness. Watershed Protection Techniques, 1994, 1(3) : 100-111.

[13] Napieralski JA, Welsh ES. A century of stream burial in Michigan (USA) cities. Journal of Maps, 2016, 12: 300-303.

[14] Elmore AJ, Kaushal SS. Disappearing headwaters: patterns of stream burial due to urbanization. Frontiers in Ecology and the Environment, 2008, 6(6): 308-312.

[15] Napieralski JA, Carvalhaes T. Urban stream deserts: Mapping a legacy of urbanization in the United States. Applied Geography, 2016, 67: 129-139.

[16] Taniguchi KT, Biggs TW. Regional impacts of urbanization on stream channel geometry: A case study in semiarid southern California. Geomorphology, 2015, 248: 228-236.

[17] Yang K, Yuan W, Zhao J et al. Stream structure characteristics and its urbanization responses to tidal river system. Acta Geographica Sinica, 2004, 59(4) : 557-564. [杨凯, 袁雯, 赵军等. 感潮河网地区水系结构特征及城市化响应. 地 理学报, 2004, 59(4): 557-564.]

[18] Yuan W, Yang K, Tang M et al. Stream structure characteristics and their impact on storage and flood control capacity in the urbanized plain river network. Geographical Research, 2005, 24(5): 717-724. [袁雯, 杨凯, 唐敏等. 平原河网地 区河流结构特征及其对调蓄能力的影响. 地理研究, 2005, 24(5): 717-724.]

[19] Han CL, Mao R. The structure characteristics and the functional variation of the river systems in Taihu Lake catchment. $J$ Lake Sci , 1997, 9(4) : 300-306. DOI : 10.18307/1997.0403. [韩昌来, 毛锐. 太湖水系结构特点及其功能的变化. 
湖泊科学, $1997,9(4): 300-306$. ]

[20] Chen YX, Xu YP, Fu WJ. Influences of urbanization on river network in the coastal areas of east Zhejiang province. Advances in Water Science, 2007, 18(1) : 68-73. [陈云霞, 许有鹏, 付维军. 浙东沿海城镇化对河网水系的影响. 水科 学进展, 2007, 18(1): 68-73.]

[21] Huang YL, Wang YL, Liu ZH et al. Stream construction characteristics in rapid urbanization area: Shenzhen city as a case. Geographical Research, 2008, 27 (5) : 1212-1220. [黄奕龙, 王仰麟, 刘珍环等. 快速城市化地区水系结构变化 特征——以深圳市为例. 地理研究, 2008, 27 (5): 1212-1220.]

[22] Zheng J, Fang WH, Shi PJ et al. Modeling the impacts of land use change on hydrological processes in fast urbanizing region-A case study of the Buji Watershed in Shenzhen city, China. Journal of Natural Resources, 2009, 24(9) : 15601572. [郑璟, 方伟华, 史培军等. 快速城市化地区土地利用变化对流域水文过程影响的模拟研究一一深圳市布 吉河流域为例. 自然资源学报, 2009, 24(9): 1560-1572.]

[23] Han LF, Xu YP, Yang L et al. Temporal and spatial change of stream structure in Yangtze River Delta and its driving forces during 1960s-2010s. Acta Geographica Sinica, 2015, 70(5): 819-827. [韩龙飞, 许有鹏, 杨柳等. 近 50 年长三 角地区水系时空变化及其驱动机制. 地理学报, 2015, 70(5): 819-827.]

[24] Yuan W, Yang K, Wu JP. River structure characteristics and classification system in river network plain during the course of urbanization. Scientia Geographica Sinica, 2007, 27(3): 401-407. [袁雯, 杨凯, 吴建平. 城市化进程中平原河网 地区河流结构特征及其分类方法探讨. 地理科学, 2007, 27(3) : 401-407.]

[25] Zhou HJ, Wang JA, Yue YJ et al. Assessment of flood hazard based on river network change: taking the Beijing-Tianjin segment of Yongding River watershed as an example. Journal of Natural Disasters, 2006, 15(6) : 45-49. [周洪建, 王静 爱, 岳耀杰等. 基于河网水系变化的水灾危险性评价——永定河流域京津段为例. 自然灾害学报, 2006, 15 (6) : 45-49.]

[26] Zhu Y, Yang JB, Zhu LF et al. The investigation of the relationship between urbanization process and climate change in Suzhou. Journal of the Meteorological Sciences, 2012, 32(3) : 317-324. [ 朱炎, 杨金彪, 朱莲芳等. 苏州城市化进程与 城市气候变化关系研究. 气象科学, 2012, 32(3) : 317-324.]

[27] Wang LY, Xu YP, Yu MJ. Analysis of the urbanization effect on the Taihu plain river network-A case study of Wuchengxiyu region of Taihu Basin. Resources \& Environment in the Yangtze Basin, 2012, 21(2): 151-156. [王柳艳, 许 有鹏, 余铭婧. 城镇化对太湖平原河网的影响——太湖流域武澄锡虞区为例. 长江流域资源与环境, 2012,21 (2) : 151-156.]

[28] Deng XJ, Xu YP. Degrading flood regulation function of river systems in the urbanization process. Science of the Total Environment, 2018, 622: 1379-1390.

[29] Li CM, Zhang SG, Yao WP et al. Study on agricultural nonpoint source pollution load of Taihu Lake Basin in Suzhou. Research of Soil \& Water Conservation, 2016, 23(3) : 354-359. [李翠梅, 张绍广, 姚文平等. 太湖流域苏州片区农业面 源污染负荷研究. 水土保持研究, 2016, 23(3) : 354-359.]

[30] Xiao JH, Shi GQ, Mao CM et al. Pre-evaluation of valuation effects of TGP on river ecosystem services. Journal of Natural Resources, 2006, 21 (3) : 424-431. [肖建红, 施国庆, 毛春梅等. 三峡工程对河流生态系统服务功能影响预评价. 自然资源学报, 2006, 21(3): 424-431.] 